\title{
Demystifying some possible limitations of CLIL (content and language integrated learning) in the EFL classroom
}

\author{
Desmistificando algunas posibles limitaciones del enfoque AICLE \\ (aprendizaje integrado de contenidos y lenguas extranjeras) en la clase \\ de inglés como lengua extranjera (LE)
}

\author{
Livia Carolina Ravelo \\ Instituto Superior Dr. Joaquín V. González \\ (Buenos Aires, Argentina)
}

\begin{abstract}
As a result of globalization, the world is constantly changing, people are overwhelmed with information and English is the language that typically serves as lingua franca to learn new content. In recent years, as a direct response to these changes, CLIL (Content and Language Integrated Learning) may be considered the approach in charge of providing suitable answers despite its possible limitations. Innovations, changes, students' needs, new resources, meaningful content and a communicative perspective are involved in CLIL, a profitable and valuable means to teaching English as a Foreign Language. The main purpose of this work is to encourage EFL teachers to implement this approach in spite of its constraints. Now the challenge seems to be finding out how this approach will lead us towards the achievement our goal.
\end{abstract}

Key Words: CLIL; limitations; implementation; EFL; teaching context.

\section{Resumen}

Como consecuencia del proceso de globalización, el mundo cambia de manera constante. El ser humano tiene acceso a diversos caudales de información, y el inglés suele ser la lengua franca que permite aprender gran cantidad de saberes. En los últimos años, y en consonancia con la problemática expuesta, el enfoque AICLE (aprendizaje integrado de contenidos y lenguas extranjeras) ha aportado respuestas apropiadas a pesar de sus posibles limitaciones. La innovación, las necesidades del alumnado, los nuevos recursos y los contenidos significativos, así también como la existencia de una perspectiva comunicativa son algunos factores que se consideran en AICLE, un valioso medio para la enseñanza del inglés. El objetivo principal de este trabajo es alentar a los docentes de inglés como lengua extranjera (LE) a implementar este método a pesar de sus falencias. Ahora, el desafío que se impone es el descubrir cómo este enfoque nos permitiría cumplir con nuestro objetivo.

Palabras Claves: AICLE; limitaciones; implementación; inglés como lengua extranjera; contexto de docencia.

\section{INTRODUCTION}

In the history of language teaching, many approaches or methodologies have been suggested for the teaching of English as a second or foreign language, each deeply 
rooted in the dominant philosophy of their historical contexts and also trying to satisfy the specific learning demands of their time. As a consequence, changes and innovations in everyday life need to be reflected in our teaching practice if one of our main interests as educators is to teach an authentic language. How, then, should we deal with these changes in the EFL classroom?

As Marianne Celce-Murcia (1980) argues, we need a historical perspective to evaluate innovations effectively. Since the turn of the millennium, foreign language teaching has found itself caught up in the complex technological and cultural developments brought about by globalization. Celce-Murcia's understanding identifies several key concepts for us: evaluation, technology, cultural developments, and globalization. If a real English is to be taught to students who expect to learn the language to satisfy their needs, we need an approach to help us evaluate what to teach through English (besides teaching English itself) - a decision that should be based on the cultural and social developments of our situational context (affected by globalization). Technological advances can also contribute to the teaching of English if we accept tools such as the Internet, video conferencing, or on-line libraries.

The current paper aims to encourage EFL teachers to implement CLIL (content and language integrated learning) despite possible limitations. Teaching innovations and changes, students' needs, new resources, meaningful content, and a communicative perspective are all bound up within CLIL - an approach which can be a profitable and valuable means for teaching English as a foreign language (EFL) in a wide variety of educational contexts.

\section{DEFINING CLIL}

Coyle, Hood, and Marsh (2010) explain CLIL ${ }^{1}$ as an educational approach in which various language-supportive methodologies are used which lead to a dualfocused form of instruction, where attention is given both to the language and the content. Graddol (2006) observes that this approach differs from a simple Englishmedium education in that it is indeed a means of teaching curriculum subjects through the medium of a language still being learned, providing the necessary language support alongside the subject specialism. CLIL can also be regarded the

\footnotetext{
${ }^{1}$ Known in Spanish as AICLE (aprendizaje integrado de contenidos y lenguas extranjeras) and in French as EMILE (enseignement de matières par intégration d'une langue étrangère).
} 
other way around: as a means of teaching English through study of a specialist content. On the same grounds, Crandall (1998) asserts that students cannot develop academic knowledge and skills without access to the language in which that knowledge is embedded, discussed, constructed or evaluated. Nor can they acquire language skills in a context devoid of academic content.

The actual implementation of CLIL involves both strong and weak versions of the above-mentioned approach, based on the unique characteristics of the context in which it is being applied. Regarding this broad categorization, Ball (2008) explains that strong CLIL means that the teaching and learning is focused primarily on the subject content, whereas in weak CLIL it is focused primarily on language. For example, strong versions would involve immersion schools (where the vehicle for communication is either a foreign language or one of the languages of a bilingual/plurilingual community), or a bilingual syllabus (where students study half their subjects in one language and the other half in another). Weak models would vary from designing didactic units (series of thematic units expected to cover more than a textbook chapter or a topic-based activity), to the study of some contents of a subject in the target language or the typical topic-based language classes (where the language teacher plans her lessons around a range of themes or topics, not solely focusing on linguistic grounds).

\section{Advantages of This Approach}

Marsh, Maljers, and Hartiala (2001) identify five cultural dimensions that are contemplated in CLIL practice: the culture dimension, the environment dimension, the language dimension, the content dimension and the learning dimension, each allowing us to identify clear advantages. With regards to the first dimension (culture), CLIL contributes to building intercultural knowledge and understanding, learning about specific neighboring countries/regions/minority groups as well as introducing the wider cultural context. The second dimension (environment) helps preparation for internationalization (specifically EU integration, as their focus is on Europe), accessing international certification, and enhancing school profiles. The third dimension (language) allows students to improve overall target language competence, develop oral communication skills, to deepen awareness of both mother tongue and target languages and to develop plurilingual interests and attitudes. In terms of content, the fourth dimension, CLIL is seen as helping to provide opportunities to study content through different perspectives, access 
subject-specific target language terminology, and to prepare for future studies and/or working life. Finally, the fifth dimension (learning), gives a place to complement individual learning strategies, to diversify methods and forms of classroom practice, as well as to increase learners' motivation.

\section{DEMYSTIFYING SOME PERCEIVED LIMITATIONS OF CLIL}

\section{CLIL transmits linguistic and cultural imperialism.}

English is, no doubt, the language of globalization. Around the globe, English is typically the lingua franca speakers of different languages resort to in order to prevent lack of communication. This language remains hegemonic, powerful, and dominant. This conception of a dominant language gives rise to what is known as "linguistic imperialism".

Phillipson (1992, p. 65) states that imperialism theory provides a conceptual framework within which English linguistic imperialism, the dominance of English worldwide, and efforts to promote the language can be understood. Scientific imperialism, media imperialism, and educational imperialism are all sub-types of cultural imperialism - as is linguistic imperialism. Linguistic imperialism also permeates all the other types of imperialism, since language is the means used to mediate and express them. Each is a theoretical construct forming part of imperialism as a global theory, concerned with the structural relations between rich and poor countries and the mechanisms to maintain inequality.

Crystal (1997) claims that English has become a global, dominant language due to the existence of a hegemonic power and ideology. World English exists as a political and cultural reality; language has no independent existence, living in some sort of mystical space apart from its speakers: "Language only exists in the brains and mouths and ears and hands and eyes of its users. When they succeed, on the international stage, their language succeeds. When they fail, their language fails." (Crystal, 1997, p. 5).

The notion of linguistic imperialism, intertwined with cultural imperialism, can be associated with one typical criticism of CLIL in curriculum design: the fact that CLIL can be used for politico-linguistic purposes, but disguised as a pedagogic philosophy. Nevertheless, even if this could be proven, it would not be a specific limitation of CLIL, since the same argument might be valid for any teaching methodology or approach, as the hidden pedagogic philosophy could be exploited 
and revealed by means of the material chosen (never deprived of some ideological component), independently of the methodology applied in the classroom.

Knowing that linguistic and cultural imperialism can exist is indeed an advantage. It allows teachers to devote careful consideration to how content should be transmitted in order to avoid imperialistic associations. As Coyle et al. (2010, p. 34) claim, tolerance and understanding are required for our pluricultural and plurilingual world to be celebrated. Studying through a different language is fundamental to fostering international understanding. In the CLIL classroom, the use of appropriate authentic materials and intercultural curricular linking can contribute to a deeper understanding of the difference and similarities between cultures. What is more, the importance relies not only on what content we want to transmit and the material chosen to fulfill our objective, but also on what version of CLIL is used to accomplish this goal. In other words, we need to know what CLIL means and what the different options of this approach are, both related to another apparent limitation known as export.

\section{No CLIL model is for export.}

The social situation in each country in general and decisions in educational policy in particular always have an effect, so there is no single blueprint of content and language integration that could be applied in the same way in different countries. In other words: no model is for export (Baetens Beardsmore, 1993, p. 39). Likewise, according to Marsh et al. (2001, p. 17), no one version of CLIL is a model for export. CLIL is said to be too diffuse since it is bound to the variables of the context in which it may be applied.

As mentioned previously, there are five dimensions based on issues relating to culture, environment, language, content, and learning. Each of these includes a number of focus points realized differently according to three major factors: agerange of learners, socio-linguistic environment, and degree of exposure to CLIL. The dimensions are usually heavily inter-related in CLIL practice. For example, in real-life implementation of CLIL, a school may wish to achieve successful outcomes in relation to more than one dimension at the same time. Moreover, just as each dimension inter-locks with others, some dimensions are more transient than others, in that the main reason for choosing CLIL in a school, or within a class, may vary over time. For example, a school might start CLIL in order to 
enhance its profile and attract students, and then move onto another objective, such as improving learners' overall target language competence.

\section{An example case}

As a primary-level EFL teacher, I would observe that a typical activity-such as asking third-graders to create a fairytale in groups (both the plot and the illustrations) - can be transformed into a larger opportunity to work on the features of this genre: for example, the presence of a good character and an evil character, royalty, poverty, and magic and enchantments. Encouraging children to reflect on these features would help them to write a fairytale plot effectively. These are some of the conclusions that were drawn from such an exercise in a bilingual school (located in the Belgrano neighborhood, CABA, Buenos Aires, Argentina): "we cannot introduce characters which do not serve a real purpose in the story", "evil characters have special powers to achieve their goal", "these powers should be made explicit in the story", and "a princess is always beautiful".

Regarding illustrations in the sample activity, students were asked to analyze the plot they had composed (by distinguishing main events from minor ones) to decide which scenes to draw. Some semiotic aspects were tackled before the illustration process: "characters should be drawn exactly the same way in all scenes, with the same physical features and wearing the same clothes" (sometimes, children do not come to an agreement on how to draw the characters and end up drawing the same character in many different ways), "changing the characters' features implies the existence of some cause-effect sequence" (for example, questions such as "why is the princess wearing a different costume here?" or "Is she in disguise for any special reason?" encourage students to evaluate their productions and eventually change them if necessary). All the aspects described here can help make any story both cohesive and coherent.

In addition, students' conclusions can become triggering elements for value debate topics. In the example case, a statement such as "a princess is generally beautiful" can make students reflect on the meaning and value of "beauty" in the society to which they belong. Regarding language competence, the first interactions were both in English and Spanish. As time went by, the participating children started talking in English more frequently. They found these kinds of activities attractive and motivating; consequently, their participation became more active. Without realizing it, they learned some basic conventional structures of the 
genre-once upon a time, and they lived happily ever after-as well as specific vocabulary, such as: talking animal, gnome, evil, demon, stepmother, stepsister, and poor shepherd. Finally, the children's assessment was carried out as an ongoing process that focused on all the parameters previously described (about the plot, the illustrations and the specific language structures and vocabulary used).

\section{Lack of appropriate teacher training and preparation.}

As discussed, this lack of exportability allows us to reflect on whether any given approach or methodology can be adopted in a pure form. Professional teachers should taken on a very active role to adapt the methodologies or approaches they apply in the classroom, taking into consideration their syllabus design, as well as the characteristics of their audience and of their educational setting. In other words, teachers need to analyze and personalize the CLIL context (Coyle et al., 2010, p. 52), which gives rise to another possible limitation with regards to teacher training.

If teachers know what CLIL means and how to apply it, they can succeed in helping their students learn with it. But having knowledge about CLIL seems to be the minimum requirement. Lack of teacher training would imply that their role as language teachers can be in real threat, as discussed by Graddol (2005):

English seems so much in demand in the world today that it may be perverse to suggest that English teachers are an endangered species. This, however, may be one consequence of a global shift towards CLIL .... The trend is likely to transform the role of English teachers and their relationship to learners and institutions. As English becomes positioned as a generic learning skill, alongside basic literacy and mathematics, and is taught to ever-younger learners, English specialists may find themselves more marginalized and their professional knowledge and experience less influential in the way English curriculums are designed and delivered. (para. 1-2)

Graddol's perspective seems rather pessimistic. However, as language becomes an instrument that allows for the transmission of content (undoubtedly, the focus in CLIL), the role of the language teacher has evolved, not deteriorated. As David Marsh (2009) asserts, formal language teaching is part of the CLIL approach, so language teachers who reposition their teaching philosophy according to the new demands could, in fact, become "conductors of the orchestra" within the new language learning framework. In addition, there is potential here for ELT 
practitioners to regenerate their profession - though if they fail to recognizie the potential of CLIL, this might result in missed opportunities.

Yet if language does not retain primary importance, since CLIL's focus is on teaching content, how is it possible to assess our students? Is there an agreed-upon framework? What do we test: content, language, or skills?

\section{Difficulties in CLIL assessment.}

This question of assessment is posed as another problematic aspect of CLIL, though it seems less like a problem if teachers understand what should be evaluated and what the evaluation process should be like. If we want our students to learn some content knowledge, the content learning is evaluated - though this does not mean that language is not tested also. If language as a system plays an important role in the transmission of content, why not penalize language mistakes when they prevent the reader from understanding the message put across? In this way, language and skills (for example, discourse organization skills) are both tested, with language understood not as the primary objective but as the vehicle for the transmission of content.

According to Keily (2009), there are two major types of language assessment. Firstly, there is language assessment as measurement, in which the goal is to determine either the level of a student or the extent to which specific language content has been learned, typically used to for program admission purposes or placement purposes. Measures of attainment usually take place at the end of a course and relate to the specific content and skills taught. Secondly, there is assessment for learning, a focus of research and development in recent years, in which assessment practices are integrated into teaching and oriented not towards a statement of level but towards enhanced learning. Keily concludes that the development of assessment practice should be based on a dialogue with teachers. This demands the development of frameworks that guide teachers in their planning and pedagogic strategies and supporting their use of these to shape schemes of work, lesson plans, worksheets, responses to written work, and (especially) microinteractions with students in CLIL classrooms. As stated in Teaching History through English - A CLIL approach (University of Cambridge ESOL Examinations, 2011):

Teachers are unsure whether to assess content, language or both. Different regions, different schools and different teachers assess in a variety of ways. What 
is important is that there is formative as well as summative assessment in CLIL subjects and that there is consistency in how learners are assessed across subjects in each school. Learners, parents and other colleagues need to know what learners are being assessed on and how they are being assessed. (p. 9)

\section{About content selection.}

This approach usually centers its conception of content on academic subjects. As a result, the social and pragmatic aspects of student interlanguage may be relatively poor. Nevertheless, these aspects might be present in the English classroom if there is interaction among peers and among peers and tutors/teachers besides the instances of information exchange. Even when the context is not that of immersion, the vehicular language can be the means of expressing one's feelings, sensations, and thoughts.

Another issue related to the subject selection is that language teachers sometimes find it difficult to support the learning of mathematics, science, or other content subjects in their language classes. Thus, co-operation and skills exchange between language and content teachers becomes an important strategy for implementing CLIL. This requires the time and the will to agree collectively on common teaching strategies and student learning activities. Stepping outside one's comfort zone into partly uncharted territory is an essential step in the CLIL journey (Mehisto, Frigols, \& Marsh, 2008, p. 27).

Considering the language dimension, it can be argued that, because of limited linguistic range, students might fail in expressing themselves and understanding content. In my view, this is a serious threat, since language can become a real obstacle if it is not sufficiently exponential. Some possible solutions to address this problem could be to focus on understanding instructions, to provide students with reading strategies (for example, by focusing on certain key words, relationship of concepts, and recognition of main ideas) that will guide them to clear understanding, and to train students to express themselves in these specific areas. This question of limited linguistic range should be considered a topic itself, alongside the development of the contents to be studied.

Finally, regarding content, determining the input may itself give rise to controversy. In CLIL, authentic materials are required to promote active learning by means of scaffolding to promote a deeper level of learning (Mehisto et al., 2008, p. 29). In my teaching environment (secondary school, Palermo 
neighborhood, CABA, Buenos Aires, Argentina), many history teachers (who are not EFL teachers) share a view that content which is culturally iconic (for example, about local affairs) should be studied in Spanish and not in English. This statement seems to be rather absurd. On similar grounds, it could possibly be argued that the Russian revolution should be studied only in Russian, effectively erasing content related to international affairs from the curriculum. On the contrary, it would be interesting to study the history of Argentina in English, making use of sources originally written in that language (the students' L2), thereby encouraging student reflection on different perceptions of the same events. For instance, comparing how the same historical event (such as the Malvinas War/Falklands War) was represented in two different newspapers (one in the L1, another in the L2) could help raise awareness about the underlying ideological trends in the different sources. Another possibility would be using translations of specific materials to work on the comparison of primary and secondary sources.

\section{CONCLUSION}

As a result of globalization, the world is constantly changing; people are overwhelmed with information, and English is the language that typically serves as the lingua franca to understand content that is not in the interlocutor's L1. In the history of the teaching and learning of the English language, methodologies and approaches have arisen to keep up with the constant social changes and philosophical movements. For instance, in Argentina, where English is taught as a foreign language, CLIL has become the chosen theoretical framework in secondary-education curriculum design (2010). This design allows for the implementation of CLIL in completely different educational settings. In the first three years of secondary school, the task-based approach is applied, which is expected to pave the way for the eventual implementation of CLIL. Considering the contextual variables of the schools in the province of Buenos Aires, the weakest versions of this approach seem to be preferred, which focus on practical aspects, such as problem-resolution activities or doing things through language, always related to the curricular contents of the students' course of studies and field of specialization.

It seems undoubtedly true that CLIL requires commitment - not only on the teacher's side, but also from the institution for which the teacher works. Certainly, the first trials will be problematic, but the process of trial and error will lead to 
better results from every new attempt. If we want to participate in these new areas of teaching, if we want our students to be better prepared, then we must keep trying, lest we-and they-miss valuable opportunities in this new era of globalization.

\section{REFERENCES}

Baetens Beardsmore, H. (Ed.). (1993). European models of bilingual education. Clevedon, UK: Multinlingual Matters.

Ball, P. (2008). How do you know if you're practising CLIL? Onestopenglish. Retrieved from http://www.onestopenglish.com/clil/methodology/articles/article-how-doyou-know-if-youre-practising-clil/500614.article

Celce-Murcia, M. (1980). New methods in perspective. Mextesol Journal, 4(4), 213.

Retrieved

from

http://www.mextesol.net/journal/index.php?page=journal\&id_article=394

Coyle, C., Hood, P., \& Marsh, D. (2010). CLIL: Content and language integrated learning. Cambridge, UK: Cambridge University Press.

Crandall, J. (1998). Collaborate and cooperate: Teacher education for integrating language and content instruction. Forum, 36(1), 2-9. Retrieved from http://dosfan.lib.uic.edu/usia/E-USIA/forum/vols/vol36/no1/p2.htm

Crystal, D. (1997). English as a global language. Cambridge, UK: Cambridge University Press.

Dirección General de Cultura y Educación de la Provincia de Buenos Aires. (2010). Diseño curricular para la educación secundaria ingles 5to año. La Plata: Publicaciones DGCyE. Retrieved from http://servicios2.abc.gov.ar/ lainstitucion/organismos/consejogeneral/disenioscurriculares/secundaria/mar co_general_ciclo\%20superior.pdf

Graddol, D. (2005, April 20). Spoken everywhere but at what cost? The Guardian Weekly. Retrieved from http://www.theguardian.com/theguardian/ 2005/apr/20/guardianweekly.guardianweekly11

Graddol, D. (2006). English next: Why global English may mean the end of 'English as a foreign language'. London, UK: The British Council. Retrieved from http://www.britishcouncil.org/learning-research-english$\underline{\text { next.pdf }}$ 
Kiely, R. (2009) CLIL: The question of assessment. Developing Teachers.com. Retrieved from: http://www.developingteachers.com/articles_tchtraining/ clil1_richard.htm

Marsh, D. (2009, August 7). Adding language without taking away. The Guardian Weekly. Retrieved from http://www.guardian.co.uk/guardianweekly/story/ $\underline{0,12674,1464367,00 . \mathrm{html}}$

Marsh, D., Maljers, A., \& Hartiala, A. (2001). Profiling European CLIL classrooms. Languages open doors. Jyväskylä, Finland: University of Jyväskylä \& European Platform for Dutch Education. Retrieved from: http://lakk.bildung.hessen.de/netzwerk/faecher/bilingual/Magazin/mat_aufsa etze/clilprofiling.pdf

Mehisto, P., Marsh, D., \& Frigols-Martín, M. J. (2008). Uncovering CLIL: Content and language integrated learning in bilingual and multilingual education. Oxford, UK: Macmillan Education.

Phillipson, R. (1992). Linguistic imperialism. Oxford, UK: Oxford University Press.

University of Cambridge ESOL Examinations. (2011). Teaching History through English - A CLIL approach. Cambridge, UK: Cambridge University Press. Retrieved from http://www.cambridgeenglish.org/images/168750-teachinghistory-through-english-a-clil-approach.pdf

\section{BIODATA}

Livia Carolina RAVELo holds a Master's degree in Discourse Analysis from the University of Buenos Aires, Argentina. She also holds an M.A. in the teaching of Spanish and English as a foreign language from the University of Jaén (Spain). She has vast experience in the teaching of English as a foreign language in primary, secondary, tertiary and university level in Argentina. Her research interests are CLIL, historical comics, and the social sciences. At present she is a lecturer in Geography and Culture of the UK and the USA, and Discourse Analysis at the Instituto Superior del Profesorado Dr. Joaquín V. González, CABA, Argentina. 